\title{
Schnyder corneal dystrophy
}

INSERM

\section{Source}

INSERM. (1999). Orphanet: an online rare disease and orphan drug data base. Schnyder corneal dystrophy. ORPHA:98967

Schnyder corneal dystrophy (SCD) is a rare form of stromal corneal dystrophy (see this term) characterized by corneal clouding or crystals within the corneal stroma, and a progressive decrease in visual acuity. 